Global Conferences Series:

Social Sciences, Education and Humanities (GCSSSEH), Volume 3, 2019

The $1^{\text {st }}$ International Conference on Education, Social Sciences and Humanities

DOI: https://doi.org/10.326/hum0189

\title{
Analysis About The Influence of Infectiveness Supervision of Teachers and Counseling Performance on The Development of Professional Identity
}

\author{
Agus Taufiq \\ Universitas Pendidikan Indonesia \\ (") $\square$ afiq@upi.edu
}

\begin{abstract}
This article is intended to explain an analysis of the ineffectiveness of the supervision of Teacher Guidance and Counseling and the negative consequences that can occur on the development of the professional identity of the guidance and counseling teacher and can erode public trust in the profession of guidance and counseling. The analysis is based on the findings of several studies related to the implementation of supervision of the guidance and counseling teacher's performance in three districts in West Java. Analysis is carried out using the integrated supervision perspective. According to this supervision perspective, the ineffectiveness of the implementation of supervision of guidance and counseling teacher performance can have a devastating effect on the development of the teacher's professional guidance and counseling identity itself, and if ignored; without serious and systematic efforts, sooner or later school counselors will lose their professional identity, and if ignored, the guidance and counseling profession will experience a crisis of trust from the wider community, especially users. Based on the results of the analysis, it is recommended that a number of strategic efforts must be made by various parties involved in the effort to organize the supervision model of the performance of relevant and effective guidance and counseling teachers.
\end{abstract}

Keywords: Supervision of performance guidance and counseling teachers (School Counselors), development of professional identity.

\section{Introduction}

Overview of the Ineffectiveness of Supervision of Teacher Guidance and Counseling Performance (School Counselors)

First, it needs to be emphasized that what is meant by supervision in this article refers to clinical supervision. Bernard J.B., and Goodyear R.K. (2014: 7) explains that clinical supervision as a typical professional pedagogy is characterized by three processes: engagement (uncertainty) and uncertainty (formation).

Copyright $\odot$ 2019, the Authors. Published by Redwhite Press. 
Engagement is involvement in learning, occurs when there is an active dialogue between school counselors as students and supervisors as educators (instructors); uncertainty is a condition in which the school counselor first feels uncertain because the results of the learning experience he has obtained are not clear to them how they are applied in an intellectual and contextual manner. Formation, refers to a situation where the school counselor processes thoughts which are then assisted by the supervisor by digging and sharpening the ideas of the school counselor to begin thinking like the way of thinking and acting a professional school counselor; apply, report and assess their own performance on an ongoing basis. Strictly speaking clinical supervision as a specific pedagogy in the guidance and counseling profession is an action pedagogy that makes the school counselor as a learner think and make his decision independently about what he will do in helping a student or group because they have a high interest in doing it according to the rules scientific rules and the guidance and counseling profession itself.

Clinical supervision is built on the basic premise: (1) clinical supervision measures have an important positive effect on those supervised by school counselors) and parties served by school counselors, he explained students; (2) clinical supervision is a separate intervention. This means that clinical supervision explains unique issues, theories and techniques in the practice of supervision, therefore every discipline within the scope of mental health disciplines requires the preparation of adequate clinical supervisor candidates; and (3) although clinical supervision in various professions has differences, in the process and skills they use more similarities without depending on the specifications of the discipline or where supervision is carried out. (Bernard J.B., and Goodyear R.K., 2014: 3).

The functions performed by supervisors in the supervision are didactic functions, consultative functions, training, and supportive functions using various approaches, methods and intervention techniques that teach (ZI Orga:), unique (Hawkins, P., \& Shohet, R. 2000;). In the context of supervision, the role carried out by supervisors is done flexibly in accordance with the needs and characteristics of professional development and personal counselors who are supervised. Roles run by supervisors range from the role of the teacher, professional skills trainer, consultant or expert, as a mentor and as a supporter or counselor to the efforts made by the counselor in overcoming his own problems that disrupt professional work and career development.

After the implementation of Law Number 14 of 2005 concerning Teachers and Lecturers, teachers and lecturers who have worked in the community must undertake in-service education and training programs to obtain certificates as professionals, so that the concerned gets recognition as a professional and is considered legitimate to receive benefits profession from the government. To find out the success of teacher education programs in positions on improving their professional performance in the schools where they are assigned. In this study, teachers who had received certificates as professional teachers including guidance and counseling teachers (school counselors) and young teachers who had not yet obtained certificates as professional teachers were the subjects of the study. The results showed that there was no significant difference between the professional performance of guidance and counseling teachers who had been certified professionally and guidance and counseling teachers who were not professionally certified (Taufiq and Sudaryat, 2012; Saripah, I., et al., Herdi et al., 2014 ) 


\section{Result and Discussion}

The results of the above research, not only occur among guidance and counseling teachers (school counselors) but occur almost thoroughly towards teachers in various fields of study. The failure to take part in the system has made the parties aware of the implementation of teacher education in positions, especially the Government and teacher educators at the Institute of Higher Education for Education (LPTK) to change the system of administering teacher education in jabata including guidance and counseling teachers (school counselors) to more appropriate direction. The results of the above research have also raised awareness among educators of prospective school counselors to conduct systematic studies and research on how to supervise the performance of school counselors. In other words, the results of the study became one of the factors behind the research of the Guidance and Counseling Supervisory Team of the University of Indonesia to reveal: "What is the portrait of the implementation of performance supervision on guidance and counseling teachers at schools that have been carried out by the supervisors? "

The following is a summary of the fundamental findings of several studies on the implementation of supervision of the performance of school counselors in West Java. The following summary is described based on the similarity of topics that emerged in research conducted in different areas, carried out by teams from the Department of Psychology of Education and UPI FIP Guidance from 2012 to 2017. (Taufiq, A., 2012; Ibrahim, 2013; Ningsih, E., 2015; Sarpah, I., et al., 20016 Ernawati, 2017).

1. Qualifications of expertise of BK supervisors. Supervisors or supervisors who supervise the performance of school counselors are mostly carried out by staff of education units or subject matter supervisors, not by supervisors with educational backgrounds and counseling and counseling professions. In the meantime, subject supervisors who supervise the performance of previous counselors do not receive adequate education and training to be able to supervise the performance of school counselors;

2. Number of supervisors with academic background Guidance and Counseling and training on Clinical Supervision Methodology. Of the 33 cities / regencies in West Java, only a small proportion ( 9 cities / districts) have a background in guidance and counseling academic education, so only a small proportion of school counselors receive supervision from supervisors with educational backgrounds and counseling and counseling professions; however, these 9 people were not previously equipped with adequate mastery of clinical supervision methodology;

3. Intensity and target focus Supervision of performance. Within one year, sometimes supervision is sometimes not. The duration of time when supervision is carried out only ranges from 45 minutes to 90 minutes. Supervision is carried out in a psoradic, unscheduled manner and there is no prior notification of the substance of performance that will be the focus of supervision. The supervisor only asked the school counselor to collect administrative evidence related to the BK program, the classi fi cation guidance unit and the number of students counseled. Supervision is only done on limited administrative aspects, not on all fundamental aspects of the school counselor's work in a comprehensive and non-tangible manner.

4. Relationship supervision and intervention carried out by the supervisor. Relationships between supervisors and school counselors are more of a relationship between superiors and subordinates than relations between two people from the same profession. Supervisors often remind that the main tasks and functions in supervision are performance appraisers who will determine the assessment and promotion of school 
counselors as civil servants / government officials or get government benefits. For this reason the supervisors ask administrative evidence to be able to provide the intended assessment. When the counselor asks about rules and arrangements related to management requirements, curriculum and problems experienced, the supervisor does not provide answers, responses and feedback that are clearly adequate.

5. Impact of performance supervision felt by guidance and counseling teachers (school counselors). Most school counselors ( $85 \%$ ) feel they are not treated and have a positive impact as expected from the experience of supervision or supervision they experience. School counselors feel the demands and evidence of performance requested by their supervisors are justified by the demands and evidence of the performance of subject teachers. Their supervisors are perceived as not having a good understanding of the knowledge and specifications of the school counselor's performance. Furthermore, the impact felt by school counselors is supervised, as follows.

a. supervision relations are merely a vehicle for fostering relations between subordinates and "bosses" whose positive effects are limited to the aspect of maintaining "good relations." fellow profession;

b. school counselors feel that they are sufficient for their professional competence and skills, because they do not receive meaningful feedback and are facilitated to develop their professional abilities. Even if they receive advice and input from their supervisors, the advice and input are only normative and general in nature, do not touch specific and significant aspects in the context of enhancing and developing their professional abilities;

c. the counselor feels that he wants to refuse unprofessional treatment and is not considered so important, so that this feeling creates resistance, antipathy, and indifference, but if it is expressed it will cause problems with evaluating performance as civil servants, so they tend to hold back, so others on other mouths in the liver. School counselors feel compelled to make unnecessary reports that are relevant to their professional duties.

d. school counselors often get misguided responses and feedback, even contrary to scientific principles and the code of ethics of the guidance and counseling profession, and are often silent and relentless just because they do not have a negative impact on evaluating themselves as civil servants or getting professional allowance from the government;

e. the school counselor feels that he does not get the expected assessment of professional work - substantially what he has done at school, because what he does is not understood by his supervisor, does not get attention and is made an element of objective and substantial assessment.

If you pay attention to the nature, goals and rules of clinical supervision fundamentals mentioned above, the findings of the study give a strong signal that the implementation of supervision of school counselors' performance that has occurred up to now tends to be wrong and ineffective, because it does not have an impact the fositif that should have happened to the attitudes, commitment and professional spirit of the supervised counselor even some findings regarding the impact felt by school counselors indicate that it can weaken or hinder the growth of the professional identity of the school counselor.

A brief description of the findings of this research is much in line with the explanations of the supervision experts about the negative impacts that arise when supervision of the performance of school counselors does not work effectively. Furthermore the negative 
effects of the ineffectiveness of supervision were put forward by Spencer \& Spencer (1998:

178 -181) which can be summarized as follows.

1. Professionals do not know the truth of their own practices anymore, do not have an acadeemic affirmation that the work they have done in this time is true or not;

2. Experiencing professional saturation (bornout), because they tend to work more on aspects of free routine work that can be done mechanically so that over time they will experience saturation to do work that demands high academic skills and professional skills because they are reluctant to read and actively participated in various seminars and workshops to update his knowledge;

3. Experiencing obsolescence or decline in professional competence. Regarding symptom number 2 above, the knowledge and skills they have from the previous academic education program become obsolete because they are no longer suitable with the real needs of the assignment. So that the longer the work of competence is not the more increasing and increasing, and even tends to decrease.

4. Slow but will definitely lose the power of professionalism. Knowledge of attitudes, and professional skills that have been owned before tend to fade or blunt, and tend to imitate and follow what is done by other people without careful consideration. They will also in turn lose their psychological strength such as honesty, openness, empathy and criticalism, thus further weakening their bargaining position in social interactions with peers.

5. Practitioners become unfamiliar with the latest concepts, approaches or technology. No longer bothered about the basic concepts, terminology, code of ethics, instruments and work equipment. This happens because he forgets the rules of knowledge he has acquired from the results of his studies, does not try to apply them consistently in the execution of his basic tasks and is lazy to read the development of knowledge in his own field.

6. Not having enough competitive power, this is a consequence of the accumulation of previous results, where a professional is unable and avoids competing with other people even in his own field even with his juniors.

7. Do not understand the technical literature in the field of profession. Let alone buying to add a reference book that is needed in their daily tasks, books that have never been read again are even removed.

8. Unable to apply the concept that is owned in the area of his specialty. Even if someone is professional at work, but he works without a concept, only works according to his common sense.

9. There is no discussion between peers about aspects of his work. In the meeting with colleagues, he did not discuss the aspects of his work, but rather discussed matters that were not relevant to the field of work.

10. Experiencing a decrease in respect and credibility from his peers, This is the result of the fact that a professional is exiled or denied because he no longer benefits in his workplace.

11. Tend to be low to be chosen as the executor of key tasks Because of the loss of knowledge capacity, skills and work ethic, a professional experiences career stagnation which will result in despair and no longer having good hopes for his career.

12. Lack of participation in decision making in his institution. Krena no longer has knowledge competencies, attitudes and work skills, so a professional is difficult to actively participate in participating in contributing energy and mind.

The research findings above are very worrying because they lead to the crisis and professional identity loss of school counselors. Therefore the findings of this study must 
receive serious attention from all parties because if left without a systematic solution, it is not impossible sooner or later can have far worse consequences for the professional performance of school counselors, guidance and counseling professions and even on educational services education received by students and the community, because professional guidance services are already seen as an integral part of the overall education effort in schools (Sunaryo Kartadinata, 2004; Dirjend Dikti, 2007; Permendikbub No 27 of 2008; Permendikbud No. 111 of 2017).

Supervision of BK Teachers' Performance Oriented in Integrated Professional Identity Development.

In the counseling profession, professional identity is at the forefront of awareness with members of the professional community. The significance of professional identity is explicitly stated in the vision of the American Counseling Association (2009) that the vision for the future of Counseling is "Sharing a professional identity together is very important for counselors". Various ways to improve the counselor's professional identity are carried out through organizational unity, legislation, licensing, communication and advocacy (Cashwell, Kleist, \& Scofield, 2009) and most importantly through effective clinical supervision (Bernard \& Goodyear, 2014; Geldard \& Geldard, 2001 ; Emerson, 2010; Gale \& Austin, 2003; Gibson, Dollarhide \& Moss, 2010; Mellin, Hunt \& Nichols, 2011).

The professional identity of the counselor is the integration of professional training with personal traits in the context of professional community life together (Nugent \& Jones, 2009). The contemporary definition of professional identity seems to revolve around three themes: self-advocacy as a professional, integration of skills and attitudes as a professional, and the perception of life in the context of a professional community. According to Reisetter et al. (2004), professional identity is the view of self as a professional plus competence as a professional, thus producing conformity between personal world views and professional views. The peak of integrating these things lies in his view as part of the professional community. Similar to the above opinion, Auxier, Hughes, and Kline (2003) state that professional identity is the same as self-awareness as a provider of assistance (the therapeutic self), which is a combination of professionals (roles, decisions, ethics) and personal self (value, morality, perception). Self-awareness as an aid provider creates a frame of reference (professional context) to carry out counseling roles and decisions, attitudes regarding responsibility and ethics, ways of thinking, and problem solving patterns.

The crucial role of clinical supervision in preparing professional staff has been recognized for a long time because of three reasons, namely: (a) in essence a professional works with great autonomy; (b) a professional needs to make judgments in the face of highly erratic conditions; and (c) a professional bases his decision on the specificity of the knowledge he controls, so that it is impossible to overcome all the difficulties he faces (Brott, \& Myers, 1999).

Although many definitions of clinical supervision are expressed differently, the definitions that tend to be agreed upon by experts in the field of Mental Health (including guidance and counseling) are the definitions of Bernard and Goodyer as follows:

" Supervision is provided by a senior member of a profession to a more junior member or member. . . . This relationship is evaluative, extends over time, and has a simultaneous purpose of enhancing the professional functioning of the more junior person (s); monitoring the quality of professional services offered to the 
clients that he, he, or they see; and serving as a gatekeeper for those who are entering the particular profession "(Bernard, J.W. \& Goodyear, R.K., 2014: 8).

Furthermore, guidance and counseling experts (such as) explain, among other things, that clinical supervision is carried out by two professional counselors, where more senior counselors build good relationships with young counselors who are supervised, monitor the quality and code of ethics of services performed to clients. the service it provides intervenes is needed with the aim of enhancing and developing supervised counselors in carrying out full professional functions.

The crucial role of supervision is the performance of guidance and counseling teachers (school counselors) who already work in schools have. In general, supervision functions to: (1) ensure that school counselors who have served in schools have educational qualifications and professional competencies in accordance with the standard set, so that they can carry out their main duties and functions as school counselors; (2) to provide assurance and protection for students or clients who are served by school counselors from the possibility of the counselor's actions and behavior that do not match and harm students; and (3) to facilitate the improvement and personal development, professionalism and career of school counselors on an ongoing basis.

Regarding the role of supervision in the development of professional identity, Corey, Corey \& Callanan explain as follows:

Supervision is the most important component in the development of a competent practitioner. It is a context of supervision that trainees begin to develop a sense of their professional beliefs and attitudes regarding clients and therapy. (Corey, Corey, \& Callanan, 2007, p.360).

Although professional identity is the top priority of the components of supervision purposes, they do not deny the other intentions of supervision when they state:

"In the literature on supervision, there seems to be a basic agreement that process supervision should concentrate on supervising professional development rather than on personal concerns and supervision and counseling have different purposes". (Corey, Corey \& Callanan, 2007, p.377)"

Corey's view, Corey \& Callanan above, is in line with Zi Orga, S, (1997) who uses the Depelopmental perspective, which sees supervision as a vehicle for specific learning, where reflections of supportive professional experience are developed along with counseling to enable school counselors to gain insight new professional and personal through their own experience. This pattern of learning under supervision is intended to help school counselors integrate practical experience with theoretical knowledge and to explore solutions to problems they face in the workplace. In addition supervision is also intended to provide support so that counselors are able to face very strong pressure and to build their professional identity. With this supervision mindset, professional learning for school counselors can grow, as well as their personal development.

Furthermore Hawkins, P., \& Shohet, R. (2000) see the ultimate goal of performance supervision as self supervision. There are a number of reasons why school counselors must be proactive in supervising themselves. First because supervision is a central form that focuses on the needs of the counselor and also on the shared responsibility of the supervisor and counselor in order to provide the best service for the client. Both supervision is a form 
of ongoing professional learning process, including helping counselors to learn to be supervisors.

The development of a school counselor's professional identity involves an exploration process and works to integrate the values, attitudes and behaviors right by a member of the community guidance and counseling in a broader identity system. (Auxier et al., 2003; Gibson et al., 2010). Furthermore Gibson et al. (2010) describe this process as the involvement of formalational tasks, including: (a) ownership of the definition of personal counseling, (b) adoption of responsibility for professional growth, and (c) recognition of professional identity linked to a broader system, in context Indonesia is connected with the Indonesian Guidance and Counseling Association (ABKIN). The counselor's transformational assignments are characterized by significant experiences, where the counselor experiences emotional fluctuations and self-confidence as a conceptual cycle and opportunities for learning experience after evaluative feedback from supervisors, direct supervisors at work and peers.

In an American Counseling Association (ACA) forum a number of experts in the counseling profession discuss the professional identity of the counselor. In the end they agreed that counselors need to have a strong professional identity to differentiate between professionals in allied fields, for the purposes of promotion and marketing, public relations, certification, accreditation, public policy, and to maximize the results of their work to the clients served. (Woodside, M., Henfield, \& Choi, (2014).

Based on a review of various literature on professional identity and the development of professional identities for various professions, Nugent and Jones (2009), concluded that the essence of professional identity is the integration of professional training and personal attributes in the context of the professional community. For professional professional identity counselors regarding how counselors learn and apply the results of their training in professional communities or professional organizations that will influence the development of their own professional identity. Relsetter, M. et al., (2004) adds that professional identity is how one not only sees himself as a professional but also how he views competence as a professional.

Regarding aspects or dimensions of professional identity, Remley and Herlihy (2014) outline six components of the counselor's professional identity, including historical knowledge and understanding, philosophical foundation, roles and functions, counselor ethics and involvement in professional organizations, and pride in being part of the professional community counseling. Some of these components can be overcome in the classroom, while professional identity is socialized through professional, interpersonal, professional practice, supervision, and network communication (Auxier, Hughes, \& Kline, 2003).

A study has identified transformational tasks in an effort to develop the professional identity of the counselor. (Dollarhide, Gibson, \& Saginak, 2008; Gibson, Dollarhide, \& Mc. Callum, 2010). This study uses a qualitative research method grounded theory, showing three transformational tasks that can specifically change and develop the professional identity of the counselor. In the initial and pre-practicum training, the participants initially had an excessive dependence on the definition of experts on counseling. However, a more personal definition of counseling appeared on them almost graduating. These definitions reflect the meaning of counseling that has been internalized and personal for the participants. Transformations occur in the ownership of the definition of counseling, responsibility for professional growth, and systemic identity or school identity. Over time, 
the process of transforming experiences moves from dependence on external validation to self-validation.

The next finding is regarding the growing sense of professional responsibility. At the beginning of the professional training the participants put their training responsibilities in charge of professional counselors to the trainers, but the next was similar to the first aspect, naming their time and activities in training, especially when interacting with clients in practicums and internships, responsibility for giving and using resources power, seeking additional supervision experience, and attending conferences experience directed changes in ownership from developing their professional identity.

With regard to the third transformation task of the dimension of professional identity, namely systemic identity (effort) which is an effort to explore various professional community tigers that influence the development of professional identity, participants training the counselor profession experience a transformation towards systemic identity. In this third dimension, the essence is; "How do they define their professional identity? In prepracticum, this definition focuses on the skills and qualities of individuals described through training standards, certification, and laws and licensing requirements. This shows their orientation towards external validation, however, before their graduation, their answers undergo transformation. Their language and thinking are more systematic and realize the importance of ongoing formal training to help clients in the future so that these transformation elements contribute greatly to their professional identity as counselors.

Other research conducted by Moss, J.M., Gibson, D.M., \& Dollarhide, C.T. (2014) also used a Grouded Theory about the transformational tasks of counselors with study subjects of counselors who had worked in the field between 5 and 20 years. This study revealed three dimensions of counselor attitudes, namely work attitude, energy in work and personal integration. The results of the study show that as more and more of their experience of working and getting clinical supervision, the counselor's work attitude undergoes a transformation from an idealistic attitude to a realist attitude, from attitudes tend to be saturated to zealous attitudes and from personality patterns that are not congruent to increasingly congruent patterns. Likewise with regard to guiding work from the desire to get guidance and validation from outside to guide and self-validation, it means that counselors tend to be more independent and responsible in professional decision making.

\section{Conclusions}

Awareness of the urgency and strategic role of supervision of the professional performance of school counselors who have been on duty has not been seriously implemented. The description of the ineffectiveness of supervision of school counselor's performance with all its negative consequences on school counselors has been very worrying because it leads to a crisis and even the professional identity loss of school counselors, therefore this relationship requires serious attention and shared concern because it occurs massively and has lasted a long time so that if ignored without immediate treatment systematic and continuous, sooner or later can have far worse consequences on the professional performance of school counselors, loss of public confidence in the profession of guidance and counseling, even on education services in schools as a whole, because of guidance and counseling in Indonesia has become an integral part of the overall education effort in schools.

In an effort to overcome the negative consequences of the ineffectiveness of clinical supervision on the performance of teacher guidance and counseling in schools, the 
following are recommended several strategic efforts that need to be carried out together, focused, serious and immediate:

1. Providing conceptual and operational guidance on supervising the performance of guidance and counseling teachers in schools that are oriented towards developing a professional identity of school counselors in an integrated and sustainable manner to be implemented systematically and continuously by supervisors. This effort is carried out synergistically between the Indonesian Guidance and Counseling Association (ABKIN), academics from the LPTK and elements of the Ministry of Education and Culture;

2. Providing supervisors who are competent in the field of guidance and counseling and mastering effective supervision methodologies in a rational amount in accordance with adequate numbers, referring to the zoning system being developed by the Ministry of Education and Culture;

3. Prepare a task force tasked with: (a) training the intended supervision model, (b) monitoring and providing periodic reports to the authorities; and,

4. Prepare an evaluative research team to assess the process and impact of implementing the supervision model on the professional performance of school counselors, report periodically, and take follow-up steps needed for its development.

\section{References}

American Counseling Association. (2009). 20I 20 statement of principles advances the profession.Retrieved from http:/ /www.counseling.org/PressRoom/NewsReleases. aspx? AGuid=4d87a0ce-65c0-407 4-89dc-276 1 ctbbe2ec

Auxier, C. R., Hughes, F. R., \& Kline, W. B. (2003). Identity development in counselors-intraining. Counselor Education and Supervision, 43, 25-38. doi:10.1002/j.15566978.2003.tb01827.x[CrossRef]

Brott, P. E., \& Myers, J. E. (1999). Development of professional school counselor identity: A grounded theory. Professional School Counseling, 2, 339-348. Bernard, J.M., \& Goodyear, R.K.(2014). Fundamentals of Clinical Supervision. (Pifth Ed.). Needham Heights: Allyn \& Bacon

Brott, P., \& Myers, J. M. (1999). Development of professional school counselor identity: A grounded theory. Professional School Counseling, 2, 339-349.

Corey,G., Corey, M.S., \& Callanan,P. (2007). Issues and Ethics in the Helping Professions. (7th Ed.). Belmont: Thompson Brooks/Cole.

Dekleva, B. (1996). Supervision For Developmental Projects-Its Understanding, Practical Implementation and Future Needs). Horizons Of Psychology, 5(2), 75-86.

Emerson, C. H. (2010). Counselor professional identity: Construction and validation of the Counselor Professional Identity Measure (Doctoral dissertation). Retrieved from ProQuest. (UMI No. 3403686).

Gale, A. U., \& Austin, D. B. (2003). Professionalism's challenges to professional counselors' collective identity. Journal of Counseling \& Development, 81, 3-10. doi:10.1002/j.15566678.2003.tb00219.x[CrossRef], [Web of Science $\left.{ }^{\circledR}\right]$

Geldard, D., \& Geldard, K. (2001). Basic Personal Counselling: A Training Manual for Counsellors. (4th Ed). Sydney: Thompson Brooks/Cole

Gibson, D. M., Dollarhide, C. T., \& Moss, J. M. (2010). Professional identity development: A grounded theory of transformational tasks of new counselors. Counselor Education and Supervision, 50, 2-79. doi:10.1002/j.1556-6978.2010.tb00106.x[CrossRef] 
Hawkins, P., \& Shohet, R. (2000). Supervision in the Helping Professions. (2nd Ed). Philadelphia: Open University Press

Herdi, dkk., (2014). Studi Deskriptif tentang pelaksanaan Supervisi Kinerja Guru Bimbingan dan Konseling (Laporan Penelitian), Bandung : LPPM UPI, Tidak diterbitkan.

Kartadinata, S. (2014). Menguak Tabir Bimbingan dan Konseling ebagai Upaya Pedagogis. Bandung: UPI Press.

Mellin, E. A., Hunt, B., \& Nichols, L. M. (2011). Counselor professional identity: Findings and implications for counseling and interprofessional collaboration. Journal of Counseling $\mathcal{E}$ Development, 89, 140-147. doi:10.1002/j.15566678.2011.tb00071.x[CrossRef], [Web of Science ®]

Moss, J.M., Gibson, D.M., \& Dollarhide, C.T. (2014). Professional identity development: A grounded theory of transformational tasks of counselors. Journal of Counseling and Development, 92, 3-12. doi: 10.1002/j.15566676.2014.00124.x

Nugent, F.A., \& Jones, K.D. (2009). Introduction to the profession of counseling (5th ed.). Upper Saddle River, NJ: Pearson.

Relsetter, M., Korcuska, J. S.. Yexley, M .. Bonds, D., Nikels, H., \& McHenry, W. (2004). Counselor educators and qualitative research: Affirming a research identity. Counselor Education and Supervision,44, 2-16.

Saripah, I., dkk., Studi Deskriptif tentang Pelaksanaan Supervisi Kinerja Guru Bimbingan dan Konseling (Laporan Penelitian Dosen Muda), Bandung: LPPM UPI, Tidak diterbitkan.

Spencer \& Spencer (1998).Copetence at Work. England: Pearson Custom Library.

Sudaryat, (2012) Studi Deskriptif tentang Pelaksanaan Supervisi Kinerja Guru Bimbingan dan Konseling (Laporan Penelitian), Bandung: LPPM UPI, Tidak diterbitkan.

Taufiq, A., Ahmad, S.N., \& Saripah, I. (2010). Supervisi kinerja guru bimbingan dan konseling/konselor (bahan ajar). Bandung: Jurusan PPB FIP UPI, Tidak diterbitkan.

Zi Orga, S, (1997). Professionals As Partners In Their Own Professional Development. 33rd IAAP International Conference on Developing Human Relations And Ethnic Understanding (Pp. 134-143). Hardwar: Gurukul Kangri University.

Woodside,M., Oberman, A. H .. Cole, K. G.. \& Carruth, E. K. (2007). Learning to be a counselor: A prepracticum point of view. Counselor Education and Supervision, 47, 14-28. 